\title{
Propofol attenuates Kupffer cell activation during hypoxia-reoxygenation
}

[Le propofol diminue l'activation des cellules de Kupffer pendant

l'hypoxie-réoxygénation]

Eon-Gi Sung MD PhD, ${ }^{*}$ Daelim Jee MD, ${ }^{*}$ In-Hwan Song MD PhD, ${ }^{*}$ Hee-Sun Kim MD PhD, ${ }^{*}$

Jae Hoon Bae MD PhD, $†$ Se-Hun Park MD $\ddagger$

Purpose: We undertook a study to determine whether propofol may attenuate Kupffer cell (KC) activation, thus protecting the cells against hypoxia-reoxygenation injury through the modulation of intracellular calcium $\left(\left[\mathrm{Ca}^{2+}\right] \mathrm{i}\right)$.

Methods: $\left[\mathrm{Ca}^{2+}\right] \mathrm{i}$, the expression of tumour necrosis factor (TNF)- $\alpha$ mRNA, and KC viability were measured in response to hypoxia-reoxygenation following pretreatment with propofol 0.5 and $5 \mu \mathrm{g} \cdot \mathrm{mL}^{-1}$ (Groups PI and P2, respectively) or without propofol (Group HRC). KCs were isolated and cultured from male Sprague-Dawley rats. KCs were incubated under an atmosphere of hypoxia $\left(95 \% \mathrm{~N}_{2}+5 \% \mathrm{CO}_{2}\right)$ for 60 min with subsequent 120 min reoxygenation ( $95 \%$ air $\left.+5 \% \mathrm{CO}_{2}\right) \cdot\left[\mathrm{Ca}^{2+}\right] \mathrm{i}$ for the first 12 min after reoxygenation, TNF- $\alpha$ mRNA, and KC viability at the end of reoxygenation in groups $\mathrm{PI}$ and $\mathrm{P} 2$ were compared with those of HRC.

Results: The increase of $\left[\mathrm{Ca}^{2+}\right]$ i from the baseline was attenuated in PI $(96.6 \pm 6.9 \%)$ and P2 (96.I $\pm 5.4 \%)$ compared with HRC (I43.8 $\pm 11.5 \%),(P<0.00 I)$, with no difference between $\mathrm{PI}$ and P2. The expression of TNF- $\alpha$ mRNA increased only in HRC during hypoxia-reoxygenation. KC viability increased in $\mathrm{PI}(97.5 \pm 2.6 \%)$ and $\mathrm{P} 2$ (94.6 $\pm 2.9 \%)$, compared with HRC $(89.9 \pm 1.4 \%),(P<0.005)$, with no difference between $\mathrm{PI}$ and $\mathrm{P} 2$.

Conclusion: The results indicate that propofol attenuates KC activation and protects KC from hypoxia-reoxygenation injury at clinically relevant concentrations. This attenuation seems to result from inhibition of $\left[\mathrm{Ca}^{2+}\right]$ i increase in $\mathrm{KC}$.
Objectif : Déterminer si le propofol diminue l'activation des cellules de Kupffer (CK), protégeant ainsi les cellules contre une lésion d'hypoxie-réoxygénation par la modulation du calcium intracellulaire $\left(\left[\mathrm{Ca}^{2+}\right] \mathrm{i}\right)$.

Méthode : Le $\left[\mathrm{Ca}^{2+}\right]$, expression du facteur de nécrose tumorale (FNT)- $\alpha A R N m$, et la viabilité des $C K$ ont été mesurés en réponse à l'hypoxie-réoxygénation suivant le prétraitement avec 0,5 et $5 \mu \mathrm{g} \cdot \mathrm{mL}^{-1}$ de propofol (Groupes PI et P2, respectivement) ou sans propofol (Groupe HRC). Des CK de rats Sprague-Dawley ont été isolées et mises en culture. Elles ont été incubées sous une atmosphère d'hypoxie $\left(95 \% \mathrm{~N}_{2}+5 \%\right.$ de $\left.\mathrm{CO}_{2}\right)$ pendant 60 min et 120 min supplémentaires de réoxygénation (95\% d'air + $5 \%\left(\mathrm{CO}_{2}\right)$. Le $\left[\mathrm{Ca}^{2+}\right]$ i pendant les 12 premières minutes après la réoxygénation, le FNT- $\alpha A R N m$ et la viabilité des CK à la fin de la réoxygénation dans les groupes $P$ l et $P 2$ ont été comparés avec ceux du groupe HRC.

Résultats : L'augmentation du $\left[\mathrm{Ca}^{2+}\right] \mathrm{i}$, au-dessus des mesures de base, a été réduite dans les groupes $P I(96,6 \pm 6,9 \%)$ et $P 2(96, I \pm 5,4 \%)$ comparés au groupe HRC (I43,8 \pm II,5 $\%)$, $(P<0,00 I)$, sans différence entre $P I$ et $P 2$. L'expression du FNT- $\alpha A R N m$ a augmenté seulement dans le groupe HRC pendant I'hypoxie-réoxygénation. La viabilité des $C K$ a augmenté dans les groupes $\mathrm{PI}(97,5 \pm 2,6 \%)$ et $\mathrm{P2}(94,6 \pm 2,9 \%)$, comparés au groupe $H R C(89,9 \pm 1,4 \%),(P<0,005)$ sans différence entre $\mathrm{Pl}$ et $\mathrm{P} 2$.

Conclusion: Le propofol diminue l'activation des CK et protège d'une lésion liée à l'hypoxie-réoxygénation des CK selon des concentrations cliniquement significatives. Cette baisse semble résulter de l'inhibition de la hausse de $\left[\mathrm{Ca}^{2+}\right]$ i dans les $\mathrm{CK}$.

From the Kupffer Cell Research Group, ${ }^{*}$ Yeungnam University College of Medicine, Daegu; the Department of Physiology, $†$ Keimyung

University School of Medicine, Daegu; and the Department of Anesthesiology, $\ddagger$ Ulsan University Hospital, College of Medicine,

University of Ulsan, Ulsan, Korea.

Address correspondence to: Dr. Daelim Jee, Department of Anesthesiology, Yeungnam University College of Medicine, Daemyung-

Dong, Nam-Gu, Daegu, Korea 705-035. Phone: 82-53-620-3367; Fax: 82-53-626-5275; E-mail: djee@med.yu.ac.kr

This research was supported by a grant of Yeungnam University Medical Center 2001.

Accepted for publication March 22, 2005.

Revision accepted May 10, 2005. 
K

UPFFER cell activation is an early feature of reperfusion after warm ischemia ${ }^{1}$ or cold preservation $^{2}$ of the liver. The activated Kupffer cells are the major source of free radicals and cytokines in hepatic ischemia-reperfusion injury and it is suggested that the increased intracellular calcium $\left(\left[\mathrm{Ca}^{2+}\right] \mathrm{i}\right)$ might be a likely consequence of Kupffer cell activation in response to hypoxia and reoxygenation. ${ }^{3}$ Further, Kupffer cells are more vulnerable to reoxygenation than to hypoxia, possibly by a self-destruction mechanism caused by an oxygen-triggered activation ${ }^{4}$ and it has been reported that Kupffer cells subjected to hypoxia-reoxygenation generate a burst of reactive oxygen species and this contributes to the self-destruction of the cells. ${ }^{5}$

In the liver, L-type calcium channel blockers have been used to attenuate activation of Kupffer cells and vasoconstriction following ischemia and reperfusion, ${ }^{6,7}$ and it is reported that Kupffer cells contained voltagedependent calcium channels. ${ }^{8}$ Previous reports demonstrated that propofol selectively inhibits calcium entry through the L-type channel in heart and vascular smooth muscle cells in a dose-dependent manner, ${ }^{9}$ and might inhibit isolated Kupffer cells. ${ }^{10}$ These observations suggest that propofol might attenuate Kupffer cell activation. However, the effects of propofol on Kupffer cells in response to hypoxia-reoxygenation have not been reported. We hypothesized that propofol may attenuate the activation of Kupffer cells, thus protecting them against hypoxia-reoxygenation injury through the modulation of $\left[\mathrm{Ca}^{2+}\right] \mathrm{i}$ in Kupffer cells. To assess this, we measured $\left[\mathrm{Ca}^{2+}\right] \mathrm{i}$ and the expression of tumour necrosis factor (TNF)- $\alpha$ mRNA as markers of activation, and Kupffer cell viability in response to hypoxia-reoxygenation following pretreatment with different concentrations of propofol.

\section{Methods}

The study was approved by the Research Ethics Committee of Yeungnam University. Male Sprague Dawley rats (300-350 g body weight.) were purchased from Hyo-Chang Sciences (Daegu, Korea). The animals had free access to food and water. All animals $(n=13)$ were anesthetized with ether and killed after isolation of the liver.

\section{Kupffer cell isolation and culture}

The liver was perfused in a circulating system for five to ten minutes with $0.05 \%$ collagenase type IV (Worthington Biochemical, Freehold, NJ, USA) in $50 \mathrm{~mL}$ Hank's balanced salt solution. The organ was removed, cut into small pieces, and digested further with $0.05 \%$ collagenase in Hank's balanced salt solu- tion. Kupffer cells were isolated using the method by Smedsrod et al. ${ }^{11}$ In brief, the cell suspension was centrifuged at $50 \times \mathrm{g}$ for two minutes to separate the parenchymal cells from the nonparenchymal cells. The resulting supernatant, which contains nonparenchymal cells, was centrifuged $(300 \times \mathrm{g} ; 4 \mathrm{~min}$; $4^{\circ} \mathrm{C}$ ) in order to concentrate the cells. Following resuspension and isopycnic centrifugation $(800 \times \mathrm{g}$; $10 \mathrm{~min} ; 4^{\circ} \mathrm{C}$ ) through a two-step Percoll gradient $(25 \%+50 \%)$, pure nonparenchymal cells banded at the interface between the two density cushions. The pellet was suspended at $4 \times 10^{6}$ cells $\cdot \mathrm{mL}^{-1}$ in RPMI1640 medium (Gibco, BRL, Grand Island, NY, USA) supplemented with $20 \%$ heat-inactivated fetal bovine serum, $100 \mathrm{IU} \cdot \mathrm{mL}^{-1}$ penicillin, and 100 $\mu \mathrm{g} \cdot \mathrm{mL}^{-1}$ streptomycin. Fractionation of these purified nonparenchymal cells into pure Kupffer cells and endothelial cells was brought by a panning technique after $15 \mathrm{~min}$ of incubation. Thus, seeding of purified nonparenchymal liver cell yielded a density of $2 \times 10^{6}$ cells. $\mathrm{mL}^{-1}$ of Kupffer cells. The purity of Kupffer cells was verified by phagocytosis of latex beads $(3 \mu \mathrm{m}$ in diameter) after $12 \mathrm{hr}$ incubation with the latex beads and exceeded $90 \%$. The cells were incubated for $48 \mathrm{hr}$ in a humidified atmosphere of $95 \%$ air and $5 \% \mathrm{CO}_{2}$ at $37^{\circ} \mathrm{C}$ in Falcon tissue culture flasks $\left(12.5 \mathrm{~cm}^{2}\right)$ for measurement of Kupffer cell viability and TNF- $\alpha$ mRNA expression, and on poly-D-lysin-coated glass cover-slips $(25 \mathrm{~mm}$ in diameter) for measurement of $\left[\mathrm{Ca}^{2+}\right] \mathrm{i}$ before being used for the experiments.

\section{Hypoxia-reoxygenation incubation (Figure 1)}

The cells were incubated under an hypoxic atmosphere $\left(95 \% \mathrm{~N}_{2}+5 \% \mathrm{CO}_{2}\right)$ for $60 \mathrm{~min}$ followed by 120 min reoxygenation $\left(95 \%\right.$ air $\left.+5 \% \mathrm{CO}_{2}\right)$. The control (Group C) incubation was normoxic conditions $\left(95 \%\right.$ air $\left.+5 \% \mathrm{CO}_{2}\right)$ for the entire experiment. The cells were incubated in a container with Luer hub ports for constant flushing with either $95 \%$ air or $95 \%$ $\mathrm{N}_{2}$. Measurements with a Clark-type $\mathrm{O}_{2}$ electrode showed the gas phase $\mathrm{PO}_{2}$ to be less than $5 \mathrm{mmHg}$ during the hypoxic period. Kupffer cells were incubated with propofol (Diprivan $\AA$, AstraZeneca, UK) in concentrations of 0.5 and $5.0 \mu \mathrm{g} \cdot \mathrm{mL}^{-1}$ (Groups Pl and $\mathrm{P} 2$, respectively) from two hours before hypoxia to the end of the experiment. Kupffer cells that were not incubated with propofol were used for the control during hypoxia-reoxygenation (Group HRC). Thus, Kupffer cells were divided into four groups for the determination of viability (\% Kupffer cell survival) and the expression of TNF- $\alpha$ mRNA: C, HRC, Pl, and P2. Kupffer cell survival (\%) and the expression of TNF- $\alpha$ mRNA were measured at the end of reoxy- 


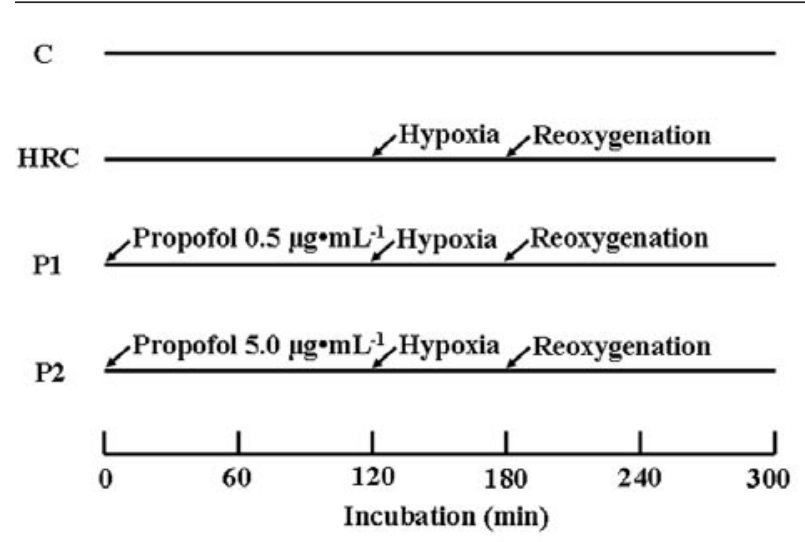

FIGURE 1 Experimental protocol

$\mathrm{C}=$ control; $\mathrm{HRC}=$ Kupffer cells subjected to hypoxia-reoxygenation; $\mathrm{Pl}=$ Kupffer cells subjected to hypoxia-reoxygenation and pretreatment of $0.5 \mu \mathrm{g} \cdot \mathrm{mL}^{-1}$ propofol; $\mathrm{P} 2=$ Kupffer cells subjected to hypoxia-reoxygenation and pretreatment of $5.0 \mu \mathrm{g} \cdot \mathrm{mL}^{-1}$ propofol.

genation. Kupffer cells for measurement of $\left[\mathrm{Ca}^{2+}\right] \mathrm{i}$ were divided into three groups: HRC, P1, and P2. $\left[\mathrm{Ca}^{2+}\right] \mathrm{i}$ was measured for the first $12 \mathrm{~min}$ after reoxygenation.

\section{Measurement of $\left[\mathrm{Ca}^{2+}\right] i$}

To test the effects of propofol on the increase of $\left[\mathrm{Ca}^{2+}\right] \mathrm{i}$ as a marker of Kupffer cell activation early during reoxygenation, cells were plated on poly-Dlysin-coated glass cover-slips $(25 \mathrm{~mm}$ in diameter $)$ at a density of $2 \times 10^{6}$ cells for measurement of $\left[\mathrm{Ca}^{2+}\right]$ i. Fura-2 acetoxymethyl (Fura-2/AM) ester was obtained from Molecular Probes (Eugene, OR, USA) and dissolved in dimethyl sulfoxide (DMSO). Physiological saline solution for measurement of $\left[\mathrm{Ca}^{2+}\right] \mathrm{i}$ contained (in $\mathrm{mM}$ ): $\mathrm{NaCl}(126), \mathrm{KCl}(5), \mathrm{CaCl} 2(1), \mathrm{MgCl} 2$ (1.2) HEPES (10), and D-glucose (10). The solution was titrated to $\mathrm{pH} 7.4$ with $\mathrm{HCl}$ and osmolality was 290 mOsm. Microfluorescent imaging of $\left[\mathrm{Ca}^{2+}\right] \mathrm{i}$ was performed on Kupffer cells loaded with the calcium indicator dye Fura-2/AM. Some of the procedures used in calcium imaging in this experiment have been described. ${ }^{12}$ Fura-2/AM $(3 \mathrm{mM})$ was added to Kupffer cells bathed in physiological saline solution at room temperature for $30 \mathrm{~min}$ followed by a 30 min wash in dye-free physiological saline solution to allow esterase conversion to free Fura-2. Cover-slips were placed on the stage of an inverted microscope and imaging was performed with a dual-wavelength system (Intracellular Imaging, Cincinnati, OH, USA).
$\left[\mathrm{Ca}^{2+}\right] \mathrm{i}$ was calculated as the relationship between the ratio of emissions at $510 \mathrm{~nm}$ from excitation at 340 and $380 \mathrm{~nm}$. Ratio images were processed every five seconds and converted to $\left[\mathrm{Ca}^{2+}\right] \mathrm{i}$ as compared to a range of such ratios obtained by measurement of Fura-2 in the presence of known concentration of calcium (Calcium Calibration Buffer Kit, Molecular Probe). Each experimental data represents the mean relative (\%) increase of $\left[\mathrm{Ca}^{2+}\right] \mathrm{i}$ compared to baseline values before reoxygenation and the data were calculated from at least 12 individually measured Kupffer cells from three separate cultures. All imaging experiments were done at room temperature $\left(20-22^{\circ} \mathrm{C}\right)$.

\section{Reverse transcriptase-polymerase chain reaction (RT- $P C R$ ) analysis for measurement of TNF- $\alpha m R N A$ gene expression}

The expression of TNF- $\alpha$ mRNA gene expression was observed as a marker of Kupffer cell activation in response to hypoxia-reoxygenation with or without propofol treatment. Total RNA was isolated with the use of Trizol solution as instructed by the manufacturer. Briefly, after addition of $1 \mathrm{~mL}$ of Trizol and $200 \mu \mathrm{L}$ of chloroform followed by centrifugation, the aqueous phase was combined with an equal volume of isopropanol. The precipitated pellet was washed with $70 \%$ ethanol and resuspended in diethylpyrocarbonatetreated water. Three hundred nanograms of total RNA per sample were reverse-transcribed using Moloney murine leukemia virus reverse transcriptase (Perkin Elmer, Norwalk, CT, USA) and oligo dT priming according to the manufacturer's instruction, at $42^{\circ} \mathrm{C}$ for $15 \mathrm{~min}$. Amplification with specific primers was performed in a Gene Amp PCR system 9600 (Perkin Elmer) for 30 cycles with a $50 \mathrm{sec} / 94^{\circ} \mathrm{C}$ denaturation, $30 \mathrm{sec} / 55^{\circ} \mathrm{C}$ annealing, $2 \mathrm{~m} / 72^{\circ} \mathrm{C}$ extension profile in case of TNF- $\alpha$, and 25 cycles with $1 \mathrm{~m} / 94^{\circ} \mathrm{C}$ denaturation, $1 \mathrm{~m} / 60^{\circ} \mathrm{C}$ annealing, $2 \mathrm{~m} / 72^{\circ} \mathrm{C}$ extension profile in case of glyceraldehyde-3-phosphate dehydrogenase (GAPDH). Amplification of mRNA for the housekeeping gene GAPDH was used as internal quality standard. Amplified products were electrophoresed on $1.5 \%$ agarose gel stained with $0.5 \mu \mathrm{g} \cdot \mathrm{mL}^{-1}$ ethidium bromide. The primer sequences were as follows: rat TNF- $\alpha$ (25l bp); sense: 5 '-atgacgacagaaagcatgatcc-3', antisense:5'-gaagatgatctgtagtgtg-3', rat GAPDH (515 bp); sense: 5'-aatgcatcctgcaccaccaa-3', antisense: 5'gtagccatattcattgtcata-3'. Similar results were obtained in three separate cultures.

\section{Measurement of viability}

Kupffer cell viability (\% Kupffer cell survival) in Groups C, HRC, P1, and P2 at the end of reoxygenation was 


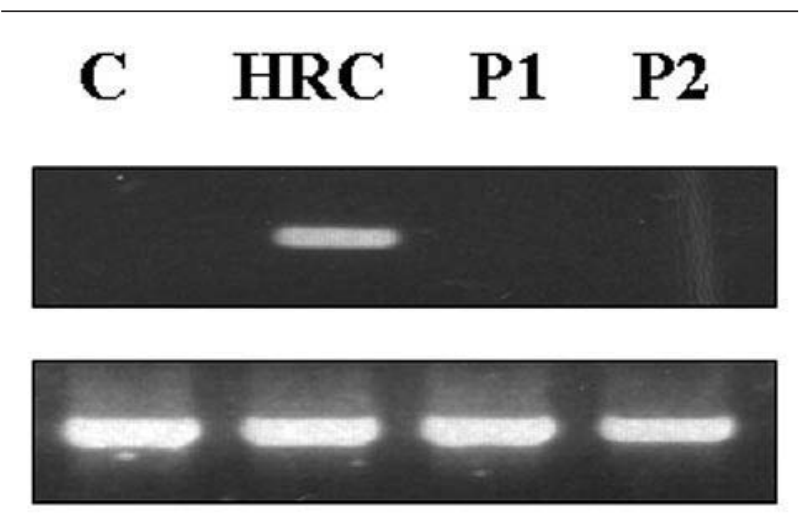

FIGURE 2 The expression of tumour necrosis factor- $\alpha$ mRNA $\mathrm{C}=$ control HRC $=$ Kupffer cells subjected to hypoxia-reoxygenation; $\mathrm{Pl}=$ Kupffer cells subjected to hypoxia-reoxygenation and pretreatment of $0.5 \mu \mathrm{g} \cdot \mathrm{mL}^{-1}$ propofol; $\mathrm{P} 2=$ Kupffer cells subjected to hypoxia-reoxygenation and pretreatment of $5.0 \mu \mathrm{g} \cdot \mathrm{mL}^{-1}$ propofol.

measured colorimetrically using the CytoTox 96® assay (Promega, Madison, WI, USA) to evaluate protective effects of propofol against hypoxia-reoxygenation injury. This assay quantitatively measures lactate dehydrogenase present in the culture medium that has been released upon lysis of the cells during the culture period. Kupffer cell survival (\%) was obtained from seven separate cultures.

\section{Statistical analysis}

Data were expressed as mean \pm SD. Statistical analysis was performed by using one-way analysis of variance with post hoc Scheffé. $P<0.05$ was considered significant.

\section{Results}

Propofol attenuated the increase of the $\left[\mathrm{Ca}^{2+}\right]$ i in Kupffer cells during bypoxia-reoxygenation

$\left[\mathrm{Ca}^{2+}\right] \mathrm{i}$ of Kupffer cells was measured to examine the effects of propofol in concentrations on Kupffer cell activation in response to hypoxia-reoxygenation. After hypoxia-reoxygenation, the increase of $\left[\mathrm{Ca}^{2+}\right] \mathrm{i}$ from the baseline was significantly $(P<0.001)$ attenuated in $\mathrm{Pl}(96.6 \pm 6.9 \%)$ and $\mathrm{P} 2(96.1 \pm 5.4 \%)$ compared with HRC $(143.8 \pm 11.5 \%)$. There was no difference in $\left[\mathrm{Ca}^{2+}\right]$ i between $\mathrm{Pl}$ and $\mathrm{P} 2$.

\section{Propofol decreased the expression of TNF- $\alpha$ mRNA}

The expression of TNF- $\alpha$ mRNA increased only in HRC during hypoxia-reoxygenation. The expression of the mRNA in Control, P1, and P2 was undetectable (Figure 2).

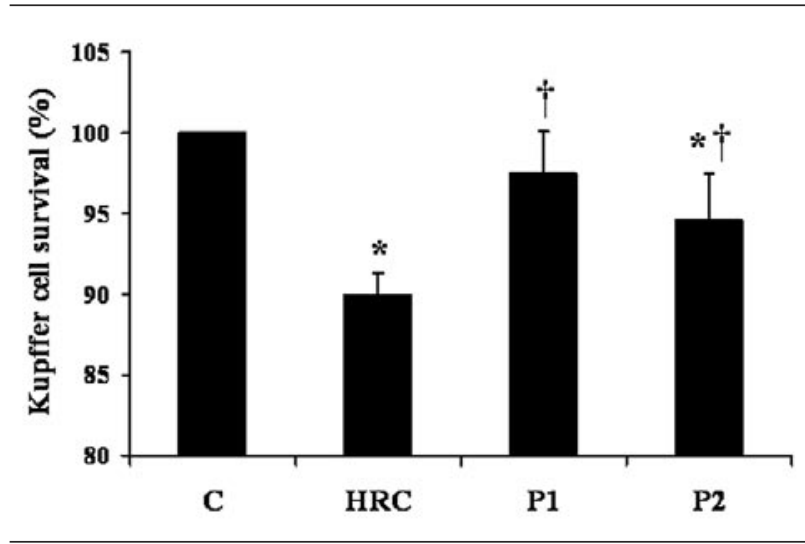

FIGURE 3 Kupffer cell viability

${ }^{*} P<0.01$ vs $\mathrm{C}, \uparrow P<0.005$ vs HRC. $\mathrm{C}=$ control; HRC $=$ Kupffer cells subjected to hypoxia-reoxygenation; $\mathrm{Pl}=$ Kupffer cells subjected to hypoxia-reoxygenation and pretreatment of $0.5 \mu \mathrm{g} \cdot \mathrm{mL}^{-1}$ propofol; P2 = Kupffer cells subjected to hypoxia-reoxygenation and pretreatment of $5.0 \mu \mathrm{g} \cdot \mathrm{mL}^{-1}$ propofol.

Propofol increased Kupffer cell viability during hypoxia-reoxygenation

The increase in Kupffer cell viability was noted in P1 $(97.5 \pm 2.6 \%)$ and P2 $(94.6 \pm 2.9 \%)$, compared with HRC $(89.9 \pm 1.4 \%),(P<0.005)$, which was most cytotoxic to Kupffer cells. When compared with Control, Kupffer cell viability was decreased in HRC and P2 $(P<0.01)$. There was no difference in Kupffer cell viability between P1 and P2 (Figure 3 ).

\section{Discussion}

Kupffer cells are known to play a major role in ischemiareperfusion ${ }^{1,13}$ or hypoxia-reoxygenation injury. ${ }^{14}$ The aim of our study was to document whether propofol could attenuate activation of Kupffer cells, and could protect Kupffer cells against hypoxia-reoxygenation injury. In the present study, the results showed that reoxygenation following one-hour hypoxia activated Kupffer cells in the rat livers and this activation was attenuated by the pretreatment of propofol in the concentrations of 0.5 and $5.0 \mu \mathrm{g} \cdot \mathrm{mL}^{-1}$, as indicated by reduced increase of $\left[\mathrm{Ca}^{2+}\right] \mathrm{i}$ and TNF- $\alpha$ mRNA expression. We found that propofol protected Kupffer cells against hypoxia-reoxygenation injury, indicated by the increased viability during hypoxia-reoxygenation.

The mechanisms by which propofol attenuates Kupffer cell activation and protects the cells from death remain unclear. Hijioka et al. ${ }^{8}$ reported that Kupffer cells contained voltage-dependent calcium channels, and propofol has been shown to block the voltage-dependent calcium channels in the heart and vascular smooth muscle cells in a dose-dependent 
manner. ${ }^{9}$ We postulate that propofol might have some effect on the calcium channels of Kupffer cells, thus attenuating the cell activation, because the increase of calcium was attenuated in Kupffer cells pretreated with propofol in the present study. Another possible mechanism might be involved. Chen et al. ${ }^{15}$ reported that a clinically relevant concentration of propofol can suppress macrophage function, possibly through inhibiting their mitochondrial membrane potential and adenosine triphosphate (ATP) synthesis without affecting cell viability. Because the Kupffer cell is basically a macrophage, these mechanisms that could be involved in the suppression of macrophages might also have a role in the attenuation of Kupffer cell activation.

Derangement of homeostasis of $\left[\mathrm{Ca}^{2+}\right] \mathrm{i}$ seems to be a detrimental factor in the cell injury. $\left[\mathrm{Ca}^{2+}\right] \mathrm{i}$ builds up during hypoxia or ischemia, increasing calciumdependent metabolic activity and activating enzymatic systems, with consequent damage to the membrane and the alteration of mitochondrial electron transport chain. Liver perfusion and transplantation studies have shown that calcium accumulation occurs in Kupffer cells. ${ }^{16}$ It was reported that therapeutic concentrations of propofol protected mouse macrophages from nitric oxide-induced cell death and apoptosis. ${ }^{17}$ Chen et al. ${ }^{15}$ also demonstrated that only a high concentration of propofol $(300 \mu \mathrm{M})$ leads to death of macrophages. Although propofol inhibited ATP synthesis of macrophages under no-hypoxia condition and suppressed macrophage function, it did not affect cell viability at 3 and $30 \mu \mathrm{M} .{ }^{15}$ In the case of hypoxia-reoxygenation, it was not reported that propofol would be cytotoxic to the macrophages in clinically relevant concentrations. Chang et al. ${ }^{17}$ demonstrated that propofol was able to protect mouse macrophages from nitric oxide-induced cell death. These reports support our finding that propofol prevents Kupffer cell death from a hypoxia-reoxygenation insult, possibly by inhibiting the increase of $\left[\mathrm{Ca}^{2+}\right] \mathrm{i}$.

The induction of an increased $\left[\mathrm{Ca}^{2+}\right] \mathrm{i}$ is known to cause prostanoid release by Kupffer cells upon hypoxia-reoxygenation. ${ }^{3}$ Lichtman et al. ${ }^{18}$ reported that nisoldipine, a calcium channel blocker, suppressed lipopolysaccharide-stimulated TNF- $\alpha$ release in Kupffer cells. These findings are consistent with our results, indicating that an increase in $\left[\mathrm{Ca}^{2+}\right] \mathrm{i}$ is associated with the activation of Kupffer cells. Activation of the cells, as Rymsa et al. ${ }^{4,5}$ reported, may lead to the self-destruction of the cells following hypoxiareoxygenation. In our study, we found that propofol preserved the viability of Kupffer cells. Taken together with these observations, propofol-induced attenuation of the increase in $\left[\mathrm{Ca}^{2+}\right] \mathrm{i}$ may play key roles in reduced expression of TNF- $\alpha$ mRNA and increased cell viability in response to hypoxia-reoxygenation in the present study.

Previous work has identified that propofol has an antioxidant activity and inhibitory effect on lipid peroxidation. ${ }^{19}$ Propofol improves the survival of rat liver cells exposed to oxidant injury at blood concentrations achieved in anesthetized patients ${ }^{20}$ or inhibits lipid peroxidation of the subcellular structure of hepatocytes from oxidative stress. ${ }^{21}$ During hepatic ischemia-reperfusion injury, neutrophils are activated and recruited into the liver. ${ }^{1}$ It was also reported that propofol attenuated the activation of the neutrophils. ${ }^{22,23}$ Considering these effects of propofol on the hepatocytes, neutrophils, and the attenuating effects of propofol on Kupffer cell activation, propofol may have a beneficial role for anesthesia in patients subjected to hepatic ischemia-reperfusion. Further, as activated Kupffer cells have an important role in the development of hepatic ischemia-reperfusion injury through the neutrophil activation and infiltration, ${ }^{13}$ we postulate that attenuation of Kupffer cell activation by propofol might further lessen neutrophil activation and infiltration.

The pharmacologic effects of propofol are highly variable among individuals, and it has been demonstrated that plasma concentrations of propofol may vary widely during a variety of clinical conditions, usually from $0.5-1.5 \mu \mathrm{g} \cdot \mathrm{mL}^{-1}$ for sedation to 2-6 $\mu \mathrm{g} \cdot \mathrm{mL}^{-1}$ for anesthesia. ${ }^{24}$ Thus, the two different concentrations of propofol used in our study are within the range of clinical use. The lower concentration $\left(0.5 \mu \mathrm{g} \cdot \mathrm{mL}^{-1}\right.$, for sedation) was also able to attenuate Kupffer cell activation as effectively as the higher concentration $\left(5.0 \mu \mathrm{g} \cdot \mathrm{mL}^{-1}\right.$, for anesthesia) of propofol.

In summary, our results indicate that propofol attenuates Kupffer cell activation and protects Kupffer cells from hypoxia-reoxygenation injury at clinically relevant concentrations. This attenuation seems to result from inhibition of $\left[\mathrm{Ca}^{2+}\right] \mathrm{i}$ increase in Kupffer cells and might play some protective roles in hepatic ischemia-reperfusion injury. These effects of propofol might be promising in liver surgery involving hypoxiareoxygenation or ischemia-reperfusion injury.

\section{Acknowledgement}

This research was supported by a grant of Yeungnam University Medical Center 2001.

\section{References}

1 Jaeschke $H$. Mechanisms of reperfusion injury after warm ischemia of the liver. J Hepatobiliary Pancreat Surg 1998; 5: 402-8. 
2 Caldwell-Kenkel JC, Currin RT, Tanaka $\Upsilon$, Thurman $R G$, Lemasters JJ. Kupffer cell activation and endothelial cell damage after storage of rat livers: effects of reperfusion. Hepatology 1991; 13: 83-95.

3 Gyenes $M$, de Groot $H$. Prostanoid release by Kupffer cells upon hypoxia-reoxygenation: role of $\mathrm{pH}_{\mathrm{i}}$ and $\mathrm{Ca}_{\mathrm{i}}{ }^{2+}$. Am J Physiol 1993; 264: G535-40.

4 Rymsa B, Becker HD, Lauchart W, de Groot $H$. Hypoxia/reoxygenation injury in liver: Kupffer cells are much more vulnerable to reoxygenation than to hypoxia. Res Commun Chem Pathol Pharmacol 1990; 68: $263-6$.

5 Rymsa B, Wang JF, de Groot $\mathrm{H}_{\text {. }} \mathrm{O}_{2}-\cdot$ release by activated Kupffer cells upon hypoxia-reoxygenation. Am J Physiol 1991; 261: G602-7.

6 Ar'Rajab A, Abren B, Bengmark S. Improved liver preservation for transplantation due to calcium channel blockade. Transplantation 1991; 51: 965-7.

7 Hisanaga M, Nakajima $\Upsilon$, Wada T, et al. Protective effect of the calcium channel blocker diltiazem on hepatic function following warm ischemia. J Surg Res 1993; 55: 404-10.

8 Hijioka T, Rosenberg RL, Lemasters JJ, Thurman RG. Kupffer cells contain voltage-dependent calcium channels. Mol Pharmacol 1992; 41: 435-40.

9 Xuan YT, Glass PS. Propofol regulation of calcium entry pathways in cultured Al0 and rat aortic smooth muscle cells. Br J Pharmacol 1996; 117: 5-12.

10 Park SH, Jee DL, Sung EG, et al. The effects of propofol on Kupffer cells in the rat liver. Korean J Anesthesiol 2002; 43: 475-84.

11 Smedsrod B, Pertoft H, Eggertsen G, Sundstrom C. Functional and morphological characterization of cultures of Kupffer cells and liver endothelial cells prepared by means of density separation in Percoll, and selective substrate adherence. Cell Tissue Res 1985; 241: 639-49.

12 Bae JH, Park JW, Kwon TK. Ruthenium red, inhibitor of mitochondrial $\mathrm{Ca}^{2+}$ uniporter, inhibits curcumininduced apoptosis via the prevention of intracellular $\mathrm{Ca}^{2+}$ depletion and cytochrome c release. Biochem Biophys Res Commun 2003; 303: 1073-9.

13 Suzuki S, Toledo-Pereyra LH, Rodriguez F, Lopez F. Role of Kupffer cells in neutrophil activation and infiltration following total hepatic ischemia and reperfusion. Circ Shock 1994; 42: 204-9.

14 Lindert KA, Caldwell-Kenkel JC, Nukina S, Lemasters JJ, Thurman RG. Activation of Kupffer cells on reperfusion following hypoxia: particle phagocytosis in a low-flow, reflow model. Am J Physiol 1992; 262: G345-50.

15 Chen RM, Wu CH, Chang HC, et al. Propofol suppresses macrophage functions and modulates mito- chondrial membrane potential and cellular adenosine triphosphate synthesis. Anesthesiology 2003; 98: 1178-85.

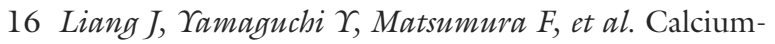
channel blocker attenuates Kupffer cell production of cytokine-induced neutrophil chemoattractant following ischemia-reperfusion in rat liver. Dig Dis Sci 2000; 45: 201-9.

17 Chang H, Tsai SY, Chang Y, Chen TL, Chen RM. Therapeutic concentrations of propofol protects mouse macrophages from nitric oxide-induced cell death and apoptosis. Can J Anesth 2002; 49: 477-80.

18 Lichtman SN, Wang J, Zhang C, Lemasters JJ. Endocytosis and $\mathrm{Ca}^{2+}$ are required for endotoxin-stimulated TNF- $\alpha$ release by rat Kupffer cells. Am J Physiol 1996; 271: G920-8.

19 Rigobello MP, Stevanato R, Momo F, et al. Evaluation of the antioxidant properties of propofol and its nitrosoderivative. Comparison with homologue substituted phenols. Free Radic Res 2004; 38: 315-21.

20 Navapurkar VU, Skepper JN, Jones JG, Menon DK. Propofol preserves the viability of isolated rat hepatocyte suspensions under an oxidant stress. Anesth Analg 1998; 87: 1152-7.

21 Eriksson O, Pollesello P, Saris NE. Inhibition of lipid peroxidation in isolated rat liver mitochondria by the general anaesthetic propofol. Biochem Pharmacol 1992; 44: 391-3.

22 Mikawa K, Akamatsu H, Nishina K, et al. Propofol inhibits human neutrophil functions. Anesth Analg 1998; 87: 695-700.

23 Nagata T, Kansha M, Irita K, Takahashi S. Propofol inhibits FMLP-stimulated phosphorylation of $\mathrm{p} 42$ mitogen-activated protein kinase and chemotaxis in human neutrophils. Br J Anaesth 2001; 86: 853-8.

24 White PF. Propofol. In: White PF (Ed.). Textbook of Intravenous Anesthesia. Baltimore: Williams and Wilkins; 1997: 111-52. 